\title{
Cisplatin resistance in urothelial carcinoma
}

Citation for published version (APA):

Skowron, M. (2018). Cisplatin resistance in urothelial carcinoma: Understanding and targeting inherent and acquired mechanisms. [Doctoral Thesis, Maastricht University]. Proefschriftmaken.nl || Uitgeverij BOXPress. https://doi.org/10.26481/dis.20180607ms

Document status and date:

Published: 01/01/2018

DOI:

$10.26481 /$ dis.20180607ms

Document Version:

Publisher's PDF, also known as Version of record

\section{Please check the document version of this publication:}

- A submitted manuscript is the version of the article upon submission and before peer-review. There can be important differences between the submitted version and the official published version of record.

People interested in the research are advised to contact the author for the final version of the publication, or visit the DOI to the publisher's website.

- The final author version and the galley proof are versions of the publication after peer review.

- The final published version features the final layout of the paper including the volume, issue and page numbers.

Link to publication

\footnotetext{
General rights rights.

- You may freely distribute the URL identifying the publication in the public portal. please follow below link for the End User Agreement:

www.umlib.nl/taverne-license

Take down policy

If you believe that this document breaches copyright please contact us at:

repository@maastrichtuniversity.nl

providing details and we will investigate your claim.
}

Copyright and moral rights for the publications made accessible in the public portal are retained by the authors and/or other copyright owners and it is a condition of accessing publications that users recognise and abide by the legal requirements associated with these

- Users may download and print one copy of any publication from the public portal for the purpose of private study or research.

- You may not further distribute the material or use it for any profit-making activity or commercial gain

If the publication is distributed under the terms of Article $25 \mathrm{fa}$ of the Dutch Copyright Act, indicated by the "Taverne" license above, 


\section{Summary}

Resistance to cisplatin-based chemotherapies remains a major problem in the treatment of patients with metastatic bladder cancer. Only $50 \%$ of the patients benefit from cisplatin-based therapies, 5-year survival is below $20 \%$, and the standard of care has not improved since decades. Since the mechanisms underlying cisplatin resistance have not been clearly defined yet, we have generated cisplatin resistant urothelial carcinoma cell lines (LTTs) by long-term cisplatin treatment and characterised phenotypical and molecular changes associated with the development of resistance. In this thesis, we investigated various mechanisms potentially contributing at pre-target (transport, metabolism), on-target (DNA-cisplatin adduct formation, DNA-damage response), post-target (evasion of apoptosis, cell-cycle arrest), and off-target (autophagy, stem cell character, epithelial-to-mesenchymal transition) levels in these urothelial carcinoma cell lines.

Long-term treated cells (LT'Ts) were significantly more resistant to cisplatin. Even though these sublines grew more slowly, they recovered fully from cisplatin-induced stress and resumed proliferation. Whereas cisplatin import and export via copper transporters remained mostly unchanged, MRP2, which can export cisplatin-glutathione (GSH) conjugates, was upregulated in LT'Ts. Accordingly, total GSH as well as several GSH biosynthesis and transport genes were increased in LTTs compared to their parental cell lines. Lower amounts of Pt-DNA-adducts and $\gamma \mathrm{H} 2 \mathrm{AX}$ foci were measured in most LTTs. Further, mRNA expression of anti-apoptotic factors, such as Survivin, was enhanced in two of four LTTs. In chapter 2 we thus concluded that cisplatin resistance in LTTs is a multi-factorial phenomenon resulting from lower platinum adduct formation, decreased DNA damage, and activated anti-apoptotic factors. Specifically, increased GSH biosynthesis in LTTs contributes to detoxification through conjugation of cisplatin with GSH and may be a promising target for opposing cisplatin resistance.

As one potential upstream regulator of increased GSH biosynthesis, we investigated the transcription factor NRF2, a major regulator of cytoprotective responses, and its crosstalk with GSH metabolism in LTTs. The results presented in chapter 3 indicated increased protein expression, nuclear translocation, and elevated transcriptional activity of NRF2 in most LTTs. The expression of cytoprotective enzymes was upregulated in LT'Ts alongside GSH levels and GSH biosynthetic enzymes. NRF2 knockdown resulted in downregulation of NRF2 targets and resensitised LTTs towards cisplatin as evidenced by reduced $\mathrm{IC}_{50}$ values, increased number of $\gamma \mathrm{H} 2 \mathrm{AX}$ foci, and increased apoptosis. Hence, activated NRF2 signalling contributes substantially to cisplatin-resistance in LT'Ts and inhibition of NRF2 could be used to resensitise UC cells to cisplatin. 
Autophagy has been identified as a cellular pro-survival process and could support post-target chemoresistance in LTTs. In chapter 4, high expression of central autophagy proteins, such as LC3II, ULK1, and RB1CC1 was reported in LT'Ts compared to their parental cell line. Accordingly, specific autophagy inhibition by SAR405 sensitised both, sensitive and LTT sublines to cisplatin-induced cytotoxicity, providing another target to overcome cisplatinresistance in UC.

The failure of cisplatin therapy could originate from less differentiated cancer stem cells (CSCs), either through innate resistance or through a selection process. A model for differentiation states in UC by Volkmer et al. (2012) correlated the expression of surface markers (CD90, CD44, and CD49f) with cytokeratins (CK14, CK5, and CK20), with CD $90^{+} / \mathrm{CK} 14^{+}$cells representing the least differentiated cells. In chapter $\mathbf{5}$, we studied whether this model holds for urothelial carcinoma cell lines (UCCs), whether $\mathrm{CD} 90^{+}$cells exhibit CSC-like properties, and whether long-term cisplatin treatment selects for $\mathrm{CD} 0^{+}$cells. However, the expression of CD90 and CK14 did not correlate in UCCs. Enrichment of CD90 ${ }^{+}$cells from UCCs by magnetic or fluorescence-activated cell sorting or by short-term cisplatin treatment, revealed neither CSC-like characteristics nor high CK14 expression. Further, the number of CD90 ${ }^{+}$cells in LT'Ts remained unchanged compared to their parental cell lines. Thus, CD90 was neither a suitable stem-cell marker in UC nor associated with cisplatin resistance. We observed instead morphological changes suggesting epithelial-mesenchymal transition (EMT) indicating that UCCs might circumvent cisplatin-induced apoptosis by phenotypic plasticity. As EMT is considered to be associated with stemness, chemoresistance, and metastatic potential, we determined the proliferative and clonogenic potential of LTTs and investigated the activity of stemness-associated signalling pathways. At the molecular level increased expression of Vimentin, TWIST, and ZEB1 and decreased E-Cadherin expression corresponded with their EMT-like morphology. In addition, WNT pathway target genes (CTNN1/ $\beta$-Catenin, AXIN2, CCND1, MYC, PITX2) were induced. However, reporter assays revealed no significant activation of canonical WNT-signalling and, accordingly, the WNT-inhibitor niclosamide did not revert cisplatin resistance. The potential of LTTs to evade cell death by a phenotypic plasticity resembling EMT is further discussed in chapter 5.

For the translation of the findings described above to clinical application, suitable models are required. For this purpose as well as for high-throughput and combination drug testing the value of experiments in $2 \mathrm{D}$ cell cultures is limited while handling efforts and costs of xenograft models often become prohibitive at larger scales. Thus, we investigated to which extent the chicken chorioallantoic membrane (CAM) model might provide an alternative 3D tool to study 
antineoplastic treatment approaches for UC. In chapter 6 the variability of tumour development on the CAM among UCCs is reported. Epithelial and mesenchymal marker expression of developed CAM tumours correlated well with 2D data. Bioluminescence images correlated with tumour weight, validating its use as an alternative readout. Various treatment schedules with cisplatin and HDACIs were explored and compared with in vitro data, revealing some dosage- and compound-dependent differences between 2D cultures and CAM tumours. Additive effects of HDACIs and subsequent cisplatin treatment observed in vitro were confirmed in the CAM model. Further, molecular characterisation of cisplatin- or HDACItreated CAM tumours revealed similar results as in $2 \mathrm{D}$ cultures. Therefore, our results demonstrated that the CAM assay is a useful tool for studying tumour growth and response to anticancer drugs under 3D conditions. It provides a good alternative to current cell culture models and could serve as a preclinical screening assay for novel therapeutic approaches. The advantages and limitations of this model compared to the murine in vivo model are discussed in chapter 7 .

The results presented in this work confirm the heterogeneity of resistance mechanisms in UC patients. The accompanying multifactorial phenomenon should be investigated in the future according to the individual resistance profile of each patient. 